the plough-plays. As has been mentioned, in these the 'killing' is loosely connected with a 'wooing' drama in which one or more suitors seek the hand of the woman. Sometimes there is no killing. Sir Edmund suggests that here we may see the merging into one of two separate classes of drama. The form occurs, it is to be noted, in an area of marginal distribution of the normal mummers' play, where indeed there also appears a connexion with the sword dance, the seasonal festival performance which in the north of England takes the place of the mummers' play. It would be of interest to inquire whether there is any evidence that the 'wooing' is a development of that sexual side of the original rite which has dropped entirely out of the mummers' play. Many of the seasonal festivals, such as the traditional Games of Ireland, and the agricultural festivals of China-perhaps a far cry-preserved this tradition by being the recognised occasion of betrothal and marriage.

The interest of the broader issues raised by this study of the folk-play must not be allowed to obscure its excellence as a record and a study of what the folk-play is or has been as a form of popular art. Both from this aspect and as an examination of the facts pertinent to its ritual origin, Sir Edmund Chambers' book is likely to stand as final.

\section{History of Wheat in Great Britain}

Wheat in Great Britain. By Dr. John Percival. Pp. $125+63$ plates. (Reading: The Author; Leighton, Shinfield, 1934.) $10 s .6 d$.

$\mathrm{P}$ ROF PERCIVAL has long been known as an able student of wheat, and an assiduous collector of its different varieties. He has not been content with obtaining ears as herbarium specimens, but has grown them so that he could study their habits of growth and compare them when placed under similar conditions. The work was at first arduous and discouraging: an older generation of Wye College students remembers him rising at 4 a.m. on summer mornings to keep the sparrows off his ripening corn. But he continued undaunted, and as a result has produced in succession sets of a remarkably extensive collection of wheat varieties suitable for colleges, a monograph which has now become the standard one on the subject, and this book which, though small in size, is packed with interesting information and is very fully illustrated.

Prof. Percival has always been able to present a subject well, and he uses this gift to great advantage in the present book. Starting from the earliest finds of wheat in Britain, grains apparently of a primitive type of Triticum vulgare found at Hembury Fort, Devon, in 1931, which seem to be definitely of Neolithic Age and dating back perhaps to 2000 B.c., he reviews in succession the later finds : grains resembling emmer (Triticum dicoccum) found in an early Bronze Age barrow, and a primitive form resembling $T$. Spelta found at Meare, the late Iron Age settlement in Somerset dating from about 150 B.c. So he goes on right through to modern times, telling us on the way a great deal that is interesting about the history of bread and of milling.

An important section of the book deals with the cultivation of wheat and the effects of climate and other conditions on its growth. Good use is made of the Rothamsted data on the subject, which are now very extensive. The methods of improving wheat are given in sufficient detail for most purposes, and the results are set out at greater length. Finally, there comes an account of the wheat varieties that are or have been grown in the British Isles. Here we miss a few that have figured in the history of agricultural science : Old Red Lanmas, the first variety to come under scientific experiment in Great Britain, being used on Broadbalk presumably because it was a standard sort on the wheat lands of Hertfordshire in the 1830's ; Red Cluster, that followed it for a time, and Red Rostock, which was retained all through the palmy days of the 1850 's, '60's and '70's. But these have long passed away and all the important kinds grown now or in living memory are here.

Altogether the book can be strongly commended to botanical and agricultural students as a compact summary of much information that they will not easily obtain elsewhere. $\quad$ E. J. RUsSELI.

\section{Quantitative Plant Ecology}

The Life Forms of Plants and Statistical Plant Geography: being the Collected Papers of $C$. Raunkiaer. Pp. xvi $+632+53$ plates. (Oxford : Clarendon Press ; London: Oxford University Press, 1934.) 35s. net.

A GREAT deal of the literature of ecology is A of a purely descriptive character, and it is not perhaps too much to say that many accounts of plant communities which are published to-day, if they add something to our information, add little to our knowledge. Such descriptions are too often the mere multiplication of examples, the working out of the same ideas upon other material without any enlargement of the philosophical concepts involved. Not the least of the debts which we owe to the Danish school of plant geographers and ecologists is that they have not been content to be merely imitators, but have extended the boundaries of our knowledge. In 